KS. GINTER DZIERŻON

Wydział Prawa Kanonicznego

Uniwersytet Kardynała Stefana Wyszyńskiego w Warszawie

\title{
NIESKUTECZNOŚĆ AKTU ADMINISTRACYJNEGO (KAN. 38 KPK)
}

Treść: Wstęp. - 1. Ewolucja brzmienia kan. 46 KPK z 1917 r. - 2. Komponenty kan. 38 KPK. - 2.1. Nieskuteczność aktu administracyjnego. - 2.2. Przyczyny nieskuteczności aktu administracyjnego. - 2.2.1. Naruszenie prawa nabytego. - 2.2.2. Przeciwieństwo względem ustawy lub zatwierdzonemu zwyczajowi. - 2.3. Możliwość wprowadzenia klauzuli uchylającej. - Zakończenie.

\section{Wstęp}

W Rozdziale I Tytułu IV Księgi I Kodeksu zatytułowanym „Normy wspólne” znajduje się kan. 38 w którym określono granice skuteczności poszczególnych aktów administracyjnych. W kanonie tym prawodawca postanowił: „Akt administracyjny, nawet wtedy gdy chodzi o reskrypt wydany $z$ własnej inicjatywy, jest pozbawiony mocy w tym, co narusza nabyte przez kogoś prawo albo jest przeciwny ustawie lub zatwierdzonemu zwyczajowi, chyba że kompetentna władza wyraźnie dołączyła klauzulę uchylającą". Zapis tego kanonu stanie się przedmiotem szczegółowej analizy w tym opracowaniu. W piśmiennictwie wskazuje się, iż bezpośrednim źródłem tej regulacji jest 46 KPK z 1917 r. 


\section{Ewolucja brzmienia kan. 46 KPK z 1917 r.}

Występujący w Kodeksie z 1917 r. kan. 46 odnosił się do reskryptów ${ }^{1}$. W trakcie prac kodyfikacyjnych jego treść została przejęta w kan. 64 Schematu Norm Ogólnych z 1977 r. . . W Schemacie tym podobny zapis wystąpił jeszcze w kan. 49 dotyczącym poszczególnych dekretów i nakazów ${ }^{3}$. Należy jednak zauważyć, iż w tym dokumencie roboczym nie występowała norma w dzisiejszym brzmieniu ${ }^{4}$. Brzmienie obecnego kan. 38 KPK pojawiło się bowiem dopiero w kan. 38 Schematu Kodeksu Prawa Kanonicznego z 1980 r. ${ }^{5}$ W porównaniu do kan. 46 KPK z 1917 r. zakres tej regulacji został poszerzony o kategorię dekretu i nakazu poszczególnego ${ }^{6}$. W „Komentarzu” autor-

\footnotetext{
${ }^{1}$ Kan. 46 miał następującą treść: „Rescripta etiam Motu proprio concessa personae de iure commune inhabili ad consequendam gratiam de qua agitur, itemque edita contra alicuius loci legitimam consuetudinem vel statutum peculiare, vel contra ius alteri iam quaesitum, non sustinentur, nisi expressa derogatoria clausula rescripto apponatur". Por. H. Soch A, Allgemeine Normen, w: Münsterischer Kommentar zum Codex Iuris Canonici, red. K. Lüdicke, t. 1, Essen 1985, ad 38, 1.

${ }^{2}$ Kan. 64 posiadał następujące brzmienie: „Rescriptum, etiam Motu proprio concessum, conferens gratiam personae de iure inhabili ad eandem consequendam, idemque editum contra alicuius loci legitimam consuetudinem vel statutum peculiare, vel contra ius alteri quesitum, effectum non habet, nisi expressa derogatoria clausula legiitime apponatur". Pontificia Commissio Codici Iuris CANonici Recognoscendo, Schema Canonum Libri I De Normis generalibus, Typis Polyglotis Vaticanis 1977, s. 26.

${ }^{3}$ Kan. 49: „Decretum praeceptumve singulare effectu caret, quatenus contrarium est legi consetudineve probatur, aut iuri alteri quaesito, nisi legitime expressa clausula derogaroria apponatur". Pontificia Commissio Codici IURIs CANONICI Recognoscendo, Schema Canonum Libri I..., s. 23; H. Socha, Allgemeine Normen, ad 38,1 .

${ }^{4}$ Por. L. Wächter, Gesetz im kanonischen Recht. Eine Rechchtsprachliche Untersuchung zum Grundproblemem der Erfassung des Gesetzes im katholischen Kirchenrecht, St. Ottilien 1989, s. 214.

${ }^{5}$ Por. Pontificia Commissio Codici Iuris Canonici Recognoscendo, Schema Codicis Iuris Canonici, iuxta animadversiones S. R. E. Cardinalium, Episcoporum Conferentiam, Dicasteriorum Curie Romanae, Universitatum Facultatumque eccelasiasticarum necnon Superiorum Institutorum vitae consacratae recognitum, Libreria Editrice Vaticana 1980, s. 10.

${ }^{6}$ Por. H. Socha, Allgemeine Normen, ad 38, 8.
} 
stwa Winfrida Aymansa i Klausa Mörsdorfa wyjaśniono, iż ujęcie w jednym kanonie materii, która stanowi przedmiot zainteresowania w tym opracowaniu nastąpiło wskutek postulatu jednej Konferencji Episkopatu ${ }^{7}$.

\section{Komponenty kan. 38 KPK}

W zapisie kan. 38 można wyróżnić następujące komponenty: nieskuteczność aktu administracyjnego, przyczyny nieskuteczności aktu oraz możliwość wprowadzenia klauzuli uchylającej.

\subsection{Nieskuteczność aktu administracyjnego}

W analizowanym kanonie ustawodawca mając na uwadze nieważność poszczególnego aktu administracyjnego operuje kategorią nieskuteczności aktu (effectu caret). Należy spostrzec, iż w tej kwestii w obowiązującej regulacji zaszły nieznaczne zmiany w porównaniu do zapisu kan. 46 KPK z 1917 r. W kanonie tym bowiem funkcjonowało słowo „sustinentur”. Na marginesie należy dodać, iż zmiana terminologiczna pojawiła się we wspomnianym już Schemacie z 1977 r.; w kan. 64 tego Schematu wystąpił bowiem zwrot „effectum non habet”; w kan. 49 natomiast znalazło się wyrażenie „effectu caret”, które występuje obecnie w kan. $38 \mathrm{KPK}^{8}$. Zdaniem kanonistów, ustawodawca poprzez nieznaczną modyfikację terminologiczną pragnął tym sposobem uniknąć nieścisłości wiążących się z funkcjonowaniem terminu „sustinentur” w kan. 46 KPK z 1917 r. ${ }^{9}$

$\mathrm{Z}$ aspektu teoretycznoprawnego nieważność aktu, o którym mowa nie jest nieważnością najbardziej radykalną w sensie niezaistnienia aktu prawnego (actus inexistens), gdyż takie jurydyczne następstwo wypływa z decyzji ustawodawcy kościelnego. W doktrynie podkreśla

\footnotetext{
${ }^{7}$ Por. W. Aymans, K. Mörsdorf, Kanonisches Recht, t. 1, Padeborn-München-Wien-Zürich 1991, s. 231.

${ }^{8}$ Por. H. Socha, Allgemeine Normen, ad 38, 2.

${ }^{9}$ Por. Tamże. Trudności interpretacyjne w tej kwestii zostały omówione m.in. przez G. Michielsa. Zob. G. Miechiels, Normae generales juris canonici, t. 2, Lublin 1929, s. 238.
} 
się, iż taki skutek prawny nie następuje automatycznie, ale trzeba go deklarować (kan. 1732-1739 KPK; PB 123) ${ }^{10}$. Takie rozwiązanie wynika z zasady wyrażonej w kan. $124 \$ 2 \mathrm{KPK}$, w myśl której „Domniemywa się ważność aktu prawnego właściwie dokonanego w jego elementach zewnętrznych"11.

Omawiając kwestię nieskuteczności aktu administracyjnego nie można nie odnieść się do normatywnego zwrotu „nawet wtedy gdy chodzi o reskrypt wydany z własnej inicjatywy" (etiam si agitur de rescripto Motu proprio dato). Według komentatorów, uwydatnienie w kan. 38 KPK tej szczególnej formy reskryptu wynika z faktu, że ustawodawca chce uniknąć wątpliwości interpretacyjnych. Reskrypty bowiem wydawane $\mathrm{z}$ własnej inicjatywy są ważne niezależnie od prawdy zawartej w motywacji tych aktów ${ }^{12}$.

2.2. Przyczyny nieskuteczności aktu administracyjnego

Jak już zasygnalizowano, w kan. 38 KPK zostały określone przyczyny nieskuteczności aktu administracyjnego. Są nimi naruszenie prawa nabytego oraz przeciwieństwo względem ustawy lub zatwierdzonemu zwyczajowi.

2.2.1. Naruszenie prawa nabytego

Prawodawca do przyczyn nieskuteczności aktu administracyjnego zalicza naruszenie nabytego przez kogoś prawa. Remigiusz Sobański w komentarzu do kan. 4 KPK określił prawa nabyte jako „[...] prawa subiektywne, ale nie te, które przysługują osobie z mocy obiektywnego prawa [...], lecz te, które ktoś nabył dzięki dokonaniu czynności

\footnotetext{
${ }^{10}$ Por. J. Miras, Comento al can. 38 CIC, w: Comentario exegético al Código de Derecho Canónico, red. A. Marzoa, J. Miras, R. Rodríguez - Ocaña, t. 1, Pamplona 1996, s. 516.

${ }^{11}$ Szerzej na ten temat zob. A. SÁNCHEZ-GIL, La presunzione di validità dell'atto giuridico nel diritto canonico, Milano 2006, s. 176-266.

${ }^{12}$ Por. V. De Paolis, A. D’Auria, Le norme generali di Diritto Canonico. Commento al Codice di Diritto Canonico, Roma 2008, s. 205.
} 
prawnej albo przez przedawnienie czy zasiedzenie"13. Zasadniczy powód przyjęcia takiego rozwiązania w kan. 38 KPK wynika z faktu, iż prawodawca pragnie chronić nabyte w oparciu o zasadę sprawiedliwości uprawnienia jednostki ${ }^{14}$.

Przedmiot szczególnej uwagi komentatorów stanowi normatywny termin „ius alteri”. Poruszając ten problem Jorge Miras wskazał, iż interpretacja tego pojęcia w odniesieniu do kan. 46 KPK z 1917 r. uległa pewnej zmianie. Kanoniści komentujący ten kanon łączyli ten termin $\mathrm{z}$ osobą inną od adresata aktu; obecnie natomiast ze względu na to, że kan. 38 KPK odnosi się także do dekretów poszczególnych we współczesnej doktrynie dominuje pogląd, zgodnie z którym w desygnacie tego pojęcia mieści się również adresat aktu ${ }^{15}$.

\subsubsection{Przeciwieństwo względem ustawy lub zatwierdzonemu zwyczajowi}

Drugim powodem wymienionym w kan. 38 KPK jest przeciwieństwo względem ustawy lub zatwierdzonemu zwyczajowi. Analizując brzmienie kanonu Miras trafnie zauważył, iż przeciwieństwo, o którym mowa, nie wynika $\mathrm{z}$ niewypełnienia elementów istotnych aktu; to bowiem wiąże się z kategorią nieważności, o której traktują kan.124\$1 i 86 KPK; dotyczy ono natomiast subiektywnej sytuacji do której się akt odnosi ${ }^{16}$.

Prezentując ten problem należy spostrzec, iż w regulacjach I Księgi Kodeksu nie wyklucza się wydania aktów administracyjnych przeciwnych ustawie. Staje się to możliwe w przypadku przywilejów (kan. $76 \mathrm{KPK}$ ) oraz dyspens (kan. $85 \mathrm{KPK})^{17}$.

\footnotetext{
${ }^{13}$ Zob. R. Sobański, Komentarz do kan. 4 KPK, w: J. Krukowski, R. Sobański, Komentarz do Kodeksu Prawa Kanonicznego, t. 1, Poznań 2003, s. 49.

${ }^{14}$ Por. A. López-Sidro López, Derechos adquiridos, w: Diccionario general de Derecho Canónico, red. J. Otaduy, A. Viana, J. Sedano, t. 3, Pamplona 2012, s. 203.

${ }^{15}$ Por. J. Miras, Comento al can. 38 CIC, s. 517.

${ }^{16}$ Por. Tamże, s. 515; H. Socha, Allgemeine Normen, ad 38, 3.

${ }^{17}$ Por. J. Miras, Comento al can. 38 CIC, s. 516. Miras twierdzi, iż bardzo trudno jest sobie wyobrazić sytuacje w których dekret byłby przeciwny ustawie lub aprobowanemu zwyczajowi.
} 
Wracając do przerwanego wątku należy stwierdzić, iż w zakresie normatywnego terminu „lex” mieszczą się zarówno ustawa w klasycznym tego słowa znaczeniu, jak również dekret ogólny (kan. 29$30 \mathrm{KPK}$ ); nie podpadają natomiast pod to pojęcie dekrety ogólne wykonawcze, ponieważ nie mają waloru ustawy (kan. 31-33 KPK) ${ }^{18}$.

Należy dodać, iż w porównaniu do kan. 46 KPK z 1917 r. pewnej zmianie ulegała terminologia dotycząca zwyczaju prawnego. W zapisie bowiem tej regulacji występowało określenie „legitima consuetudo”; w kan. 38 KPK występuje zaś pojęcie „consuetudo probata”. Według Huberta Sochy, termin „probata” jest równoznaczny z terminem „aprobata"19. W omawianej regulacji idzie więc o zwyczaj posiadający walor ustawy (kan. $23 \mathrm{KPK})^{20}$. Co ciekawe, w kan. 1515 KKKW powrócono ponownie do pojęcia „legitima consuetudo”. Alejandro Bunge uznał zapis ten za bardziej precyzyjny ${ }^{21}$.

Trzeba podkreślić, iż tak sformułowana w kan. 38 KPK zasada genetycznie wypływa $z$ zasady legalności ${ }^{22}$. Akt administracyjny bowiem może zostać wydany jedynie w obszarze prawa. Zwykle decyzja administracyjna, o której mowa w tej regulacji jest niczym innym jak aplikacją obowiązującej ustawy, czy zwyczaju prawnego do konkretnego przypadku (przypadków) ${ }^{23}$. Owszem, w kanonicznym porządku prawnym przywileje przeciwne prawu lub dyspensy rozluźniające ustawę w poszczególnym przypadku mogą być legalnie wydane, ale co trzeba $\mathrm{z}$ całym naciskiem podkreślić, staje się to możliwe, gdyż

\footnotetext{
${ }^{18}$ Por. V. De Paolis, A. D’Auria, Le norme generali..., s. 205; G. Dzierżon, Ogólne dekrety wykonawcze w kanonicznym porządku prawnym, Forum Iuridicum 4 (2005), s. 193-195.

${ }^{19}$ Por. H. Socha, Allgemeine Normen, ad 38, 5.

${ }^{20}$ Por. V. De Paolis, A. D’Auria, Le norme generali..., s. 205; L. Chiappetta, $l l$ Codice di Diritto Canonico. Commento giuridco-pastorale, t. 1, Roma 1996, s. 93.

${ }^{21}$ Por. A. Bunge, Las claves del Código. El libro I del Código de Derecho Canonico, Buenos Aires 2006, s. 125.

${ }^{22}$ Por. J. Krukowski, Administracja w Kościele. Zarys kościelnego prawa administracyjnego, Lublin 1985, s. 156; H. SocH A, Allgemeine Normen, ad 38, 7; A. Bunge, Las claves del Código. El libro I..., s. 125.

${ }^{23}$ Por. J. Krukowski, Komentarz do kan. 38 KPK, w: J. Krukowski, R. Sobański, Komentarz do Kodeksu Prawa Kanonicznego, t. 1, Poznań 2003, s. 101.
} 
zezwala na to prawo ${ }^{24}$. Jeśli natomiast inny akt administracyjny zostałby wydany przeciw ustawie, to jest rzeczą zrozumiałą, iż byłby on pozbawiony mocy prawnej.

\subsection{Możliwość wprowadzenia klauzuli uchylającej}

W interpretowanym kan. $38 \mathrm{KPK}$ zawarto jeszcze zastrzeżenie typu, „chyba że kompetentna władza wyraźnie dołączyła klauzulę uchylającą". W doktrynie wprowadzenie takiej klauzuli uznaje się za wyjątek od reguły generalnej ${ }^{25}$. Rozważając tę kwestię komentatorzy twierdzą, iż pojęcie „klauzula uchylająca” jest nieprecyzyjne. W ich przekonaniu, nieprecyzyjność wynika z tego powodu, że klauzula derogacyjna nie uchyla obowiązującej ustawy lub zwyczaju prawnego, ale odnosi się do konkretnego przypadku ${ }^{26}$. Podjęta przez kompetentną władzę decyzja w takiej formie w praktyce wiąże się z wykonaniem aktu administracyjnego ${ }^{27}$.

Teodoro Jimenéz Urresti utrzymuje, iż kompetencja o której mowa w kan. 38 KPK może zostać udzielona na mocy samego prawa, jak to ma na przykład miejsce w przypadku możliwości udzielenia dyspensy w sytuacji szczególnej (kan. 87 KPK), bądź też na skutek decyzji prawodawcy, jak to ma miejsce w przypadku udzielenia przywileju (kan. $76 \mathrm{KPK}$ ) a także w wypadku udzielenia uprawnień habitualnych (kan. $132 \mathrm{KPK}$ ) lub delegacji (kan. $133 \mathrm{KPK}$ ). Według tego hiszpańskiego kanonisty, uprawnienie to nie dotyczy jednak możliwości wprowadzenia klauzuli derogacyjnej w odniesieniu do praw nabytych, ponieważ nabycie takich szczególnych uprawnień zwykle jest następstwem decyzji władzy różnej od tej, która wydała akt administracyjny ${ }^{28}$.

\footnotetext{
${ }^{24}$ Por. V. De Paolis, A. D’Auria, Le norme generali..., s. 205.

${ }^{25}$ Por. J. García Martín, Le norme generali del Codex Iuris Canonici, Roma 1999, s. 190; V. De Paolis, A. D’Auria, Le norme generali..., s. 206.

${ }^{26}$ Por. J. Miras, Comento al can. 38 CIC, s. 518; H. Socha, Allgemeine Normen, ad $38,12$.

${ }^{27}$ Por. L. Chiappetta, $l l$ Codice..., s. 93.

${ }^{28}$ Por. T. Jimenéz Urresti, Comentario al can. 38 CIC, w: Código de Derecho Canónico. Edición bilingüe comentada, red. L. De Echeveria, Madrid 1985, s. 45.
} 
Rozpatrując ten wątek należy przypomnieć, że do problemu odwołania praw nabytych odniósł się prawodawca w kan. 4 KPK stwierdzając, iż co do praw nabytych przed wejściem w życie tego Kodeksu byłoby to możliwe, jeśli kanony tego Kodeksu wyraźnie by je odwoływały.

Kontynuując te analizy należy stwierdzić, iż zapis kan. 38 KPK dotyczy aktu lub aktów przyszłych. Gdy idzie zaś o prawa nabyte po promulgacji Kodeksu z 1983 r., to należy spostrzec, iż w zbiorze tym znajduje się tylko jedna regulacja w której stworzono taką możliwość, jaką jest kan. $177 \$ 2$ KPK dotyczący kwestii nieprzyjęcia kanonicznego wyboru przez elekta. W kanonie tym bowiem postanowiono, iż „Gdy elekt nie przyjął wyboru, traci wszelkie prawo uzyskane wskutek wyboru [...]"29.

Według zasad funkcjonujących w nowym Kodeksie utrata praw nabytych staje się możliwa także na drodze sankcji. Taką ewentualność ujęto w kan. 84 KPK dotyczącym nadużywania władzy uzyskanej wskutek udzielonego przywileju ${ }^{30}$. Pozbawienie tych szczególnych uprawnień może też mieć miejsce w następstwie pozbawienia urzędu (kan. $196 \mathrm{KPK})^{31}$. Z odwołaniem pośrednim praw nabytych mamy natomiast do czynienia w przypadku dyspensy od małżeństwa ważnego a niedopełnionego, w sytuacji gdy jeden $\mathrm{z}$ małżonków jest temu przeciwny (kan. $1142 \mathrm{KPK})^{32}$. Zdaniem kanonistów, wprowadzenie w kanonicznym porządku prawnym takich rozwiązań wynika $z$ tej racji, że w pewnych szczególnych sytuacjach zostają w poważny sposób naruszone zasady sprawiedliwości ${ }^{33}$.

\footnotetext{
${ }^{29}$ Por. G. DzIERżon, Powierzenie urzędu kościelnego poprzez wybór. Komentarz do regulacji zawartych $w$ Księdze I Kodeksu Prawa Kanonicznego, Kraków 2012, s. 118; A. López-Sidro López, Derechos adquiridos, s. 203.

${ }^{30}$ Szerzej na ten temat zob. G. DzIERżon, Pozbawienie przywileju (kan. $84 \mathrm{KPK}$ ), w: Servabo legem tuam in toto corde meo. Księga pamiątkowa dedykowana Księdzu Profesorowi Józefowi Krzywdzie CM, dyrektorowi Instytutu Prawa Kanonicznego UPJPII z okazji 70. rocznicy urodzin, red. A. Zakręta, A. Sosnowski, Kraków 2013, s. 251-257.

${ }^{31}$ Por. T. Jimenéz Urresti, Comentario al can. 38 CIC, s. 45.

${ }^{32}$ Por. Tamże.

${ }^{33}$ Por. J. Rubio Rodríguez, Los derechos adquiridos en el Codex de 1917 y 1983, Revista Española de Derecho Canonico 39 (1983), s. 450.
} 
Kolejny warunek ujęty w kan. 38 KPK dotyczy wyraźnego charakteru klauzuli; takiego zastrzeżenia się bowiem nie domniemywa się $^{34}$. Wydaje się, iż precyzyjniejszy zapis wystąpił w kan. 48 Schematu z 1912 r. Propozycja ta brzmiała następująco: „nisi derogatoria rescribendis voluntatae certo constet" 35 .

W doktrynie podkreśla się, iż uchylnie o którym mowa może zostać dokonane zarówno w sposób „explicite”, jak i „implicite”; zostaje dokonane „explicite” jeśli jest to wyraźnie powiedziane; zostaje dokonane „implicite”, jeśli w dokumencie użyto przykladowo takich formul, jak: „non obstante quacumquae lege aut consuetudine contraria”, bądź tė̇ „contrariis quibuscumque etiam speciali mentione dignis non obstantibus" 36 .

Wprowadzenie takiego rozwiązania jest w pełni zasadne, ponieważ sprawujący władzę niejednokrotnie spotykają się z sytuacjami szczególnymi, które nie mieszczą się w zakresie funkcjonujących ustawy lub dekretu ogólnego. Chociaż są one nielegalne, to jednak formalnie nie są nieważne. Dlatego też prawodawca opowiada się za możliwością wprowadzenia klauzuli uchylającej ${ }^{37}$.

Przedmiotem uwagi komentatorów stał się termin „władza kompetentna”. Przekonują oni, iż autor aktu administracyjnego nie otrzymuje władzy do wydania klauzuli na mocy kanonu ${ }^{38}$. Utrzymują oni, iż takiej decyzji nie mógłby podjąć autorytet dysponujący wyłącznie władzą wykonawczą, lecz może ją podjąć autorytet posiadający władzę ustawodawczą ${ }^{39}$. W opinii Józefa Krukowskiego, zapis kan. 38 KPK stwarza jednak możliwość dołączenia takiej kompetencji do

\footnotetext{
${ }^{34}$ Por. J. García Martín, Le norme generali..., s. 191.

${ }^{35}$ Por. A. van Hove, Commentarium Lovaniense, cz. 1, t. 4, Mechelenae-Romae 1936, s. 170.

${ }^{36}$ Por. H. Socha, Allgemeine Normen, ad 38, 12.

${ }^{37}$ Por. T. Jimenéz Urresti, Comentario al. can. 38 CIC, s. 45.

${ }^{38}$ Por. Tamże, s. 44.

${ }^{39}$ Por. J. García Martín, Le norme generali..., s. 190; V. De Paolis, A. D’Auria, Le norme generali..., s. 206; P. LombardíA, Commento al can. 38 CIC, w: Codice di Diritto Canonico e le leggi complementari, red. J. Arrieta, Roma 2007, s. 98; A. Bunge, Las claves..., s. 125.
} 
urzędu. To szczególne uprawnienie może więc pochodzić z innego tytułu, aniżeli urząd sprawowany w sposób zwyczajny ${ }^{40}$. Wyjaśniając tę kwestię kanonista ten skonstatował: „W wypadku, w którym organ kościelnej władzy administracyjnej chce wydać akt administracyjny sprzeczny z aktem prawodawczym lub zwyczajem mającym aprobatę, musi wyraźnie opatrzyć go klauzulą derogacyjną, czyli uchylającą moc obowiązującej normy prawnej, oraz wskazać, iż posiada do tego kompetencję na mocy swego urzędu lub na mocy uzyskanej delegacji ze strony wyższego przełożonego"41.

\section{Zakończenie}

Podsumowując należy stwierdzić, iż w kan. 38 KPK określono zasady dotyczące nieskuteczności poszczególnego aktu administracyjnego tylko z jednej perspektywy, jaką jest zawartość aktu ${ }^{42}$. Przyjęte $\mathrm{w}$ tej regulacji ustalenia pozostają $\mathrm{w}$ ścisłym związku z zasadą legalności. Analizując ten zapis nie trudno oprzeć się wrażeniu, iż ustawodawca kościelny jest daleki od pozytywistycznego legalizmu. Stwarza on bowiem możliwość dołączenia klauzuli derogacyjnej odnoszącej się do konkretnego przypadku. W opinii Valesio De Paolisa i Andrei D’Auria, wprowadzenie takiej ewentulaności jest konieczne, gdyż ustawa nie może stać się jedynym punktem odniesienia w wykonywaniu władzy. Sprawowujący bowiem władzę administracyjną niejednokrotnie spotykają się z sytuacjami o charakterze szczególnym ${ }^{43}$. Tego typu klauzule należy zatem uznać za „normae singulares"44. Zasadnicza racja funkcjonowania takiego rozwiązania wynika $\mathrm{z}$ faktu, iż jednym z głównych celów funkcjonowania kanonicznego porządku prawnego i stosowania prawa w tym systemie jest

\footnotetext{
${ }^{40}$ Por. J. Krukowski, Komentarz do kan. 38 KPK, s. 102.

${ }^{41}$ Por. Tenże, Administracja..., s. 156.

${ }^{42}$ Por. J. García Martín, Le norme generali..., s. 190; T. Jimenéz Urresti, Comentario al. can. 38 CIC, s. 44.

${ }^{43}$ Por. V. De Paolis, A. D’Auria, Le norme generali.., s. 206.

${ }^{44}$ Por. L. WÄCHTER, Gesetz im kanonischen Recht, s. 223.
} 
umożliwienie realizacji uprawnień wiernych w perspektywie dobra wspólnego $^{45}$.

W konkluzji nie można jeszcze pominąć jednej kwestii, mianowicie, trzeba podkreślić, iż możliwość wprowadzenia klauzuli derogacyjnej nie odnosi się do mechanizmów funkcjonowania takich instytucji, jak przywileje, czy też dyspensy, gdyż przeciwieństwo względem ustawy jest wpisane w ich naturę; dotyczy ono natomiast odrębnej możliwości podjęcia takiej decyzji w szczególnej sytuacji przez autorytet posiadający takie kompetencje.

\section{Ineffectiveness of an administrative act (can. 38 CIC)}

The author of the presented article carried out a thorough interpretation of canon 38 CIC. According to the analyses he carried out, canon $38 \mathrm{CIC}$ specifies the rules concerning the ineffectiveness of a particular administrative act only from one view, namely from the perspective of the contents of an act. The solutions suggested in the regulation remain in close relation with the rule of legality.

The author believes that the ecclesial legislator is far form positivistic legalism since he makes it possible to insert a derogative clause concerning a specific case. According to the author, such a solution is necessary because a given law cannot be the sole point of reference in exercising power. This is because in exercising administrative power one often comes across very specific situations. Therefore, including such a clause should be considered as "normae singulares".

SŁOWA KLUCzOWE: akt administracyjny, nieskuteczność aktu, kanoniczny porządek prawny

KEY wORDS: administrative act, ineffectiveness of an act, canonical legal order

\footnotetext{
${ }^{45}$ Por. G. Feliciani, La dimensione giuridica della libertà dei fedeli, w: Il concetto di diritto canonico. Storia e prospettive, red. C. J. Errázutiz, L. Navarro, Milano 2000, s. 168-172; J. CANOSA, Il rescritto come atto amministrativo nel diritto canonico, Milano 2003, s. 182-188.
} 
Nota o Autorze:

Ks. PROF. ZW. DR hAB. GINTER DzIERżon - profesor zwyczajny, kierownik Katedry Teorii i Norm Ogólnych Prawa Kanonicznego na Wydziale Prawa Kanonicznego UKSW. Autorem ponad 160 opracowań naukowych z zakresu prawa małżeńskiego, norm ogólnych prawa kanonicznego oraz teorii prawa. Członek Consociatio Internationalis Iuris Canonici Promovendo (Rzym) oraz Stowarzyszenia Kanonistów Polskich. 